\title{
Education And SMME Business Growth: A Gender Perspective From South Africa
}

Pradeep Brijlal, University of the Western Cape, South Africa

Visvanathan Naicker, University of the Western Cape, South Africa

Ricardo Peters, University of the Western Cape, South Africa

\begin{abstract}
Entrepreneurship is becoming an increasingly important source of employment for women in many countries. Policymakers and other stakeholders typically fail to differentiate between the needs of different SMME sectors when designing support programmes. Using survey data obtained from SMME owner managers in the Western Cape, this article attempts to identify whether the level of education and gender has an impact on business growth. A survey instrument in the form of a questionnaire was utilized to capture the data from 369 face-to-face interviews. The findings from this research reveal a positive relationship between the level of education of business owners and their respective business abilities to increase business growth. There were no significant differences between men and women in relation to business growth. The research has implications for policymakers seeking to understand the factors that influence business growth.
\end{abstract}

Keywords: Entrepreneurship; Education; Business Growth; Gender; SMMEs

\section{INTRODUCTION}

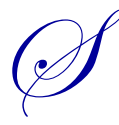

mall, medium and micro-enterprises (SMMEs) have been an important research field among academics for a considerable length of time. In developing economies, such as South Africa, SMMEs are viewed as engines of economic progress, job creation and social adjustment (Gurol \& Atsan, 2006). With the South African economy being in transition - just over eighteen years into the new democracy - SMMEs are now accounting for an increasingly greater proportion of employment growth and economic activity (DTI, 2005).

For almost five decades, there has been sustained and continued interest in entrepreneurial and business growth from policymakers, practitioners, and academics. As is clear from the literature, however, large and/or growing firms do not necessarily equate to profitable performance (Davidsson, Steffens \& Fitzsimmons, 2005). Small business growth has been the focus of many studies (Dobbs \& Hamilton, 2007) and some researchers argue that our understanding of growth in smaller businesses is still rather limited (Kirkwood, 2009). It is accepted worldwide that the development and growth of SMMEs can play an important role in job creation, social stability, and economic welfare across the globe.

It is for these reasons that the proliferation of small businesses in South Africa is beneficial. This proliferation is also welcome in view of the fact that the official unemployment rate in South Africa remains at a high of $25 \%$.

South Africa has a population of 52 million and women make up about $52 \%$ of the population (Census, 2011). Men still constitute the majority of SMME owners in South Africa. There are numerous instances where gender differences in entrepreneurial activity are well documented in the literature (Gatewood, Carter, Brush, Greene, \& Hart, 2003). Nevertheless, according to De Bruin, Brush and Welter (2006), the number of women entrepreneurs has increased dramatically. A study by Acs, Arenius, Hay and Minniti (2005) indicates that almost twice as many men as women become entrepreneurs and that these differences are consistent across a few countries. 
However, the increase in business growth may or may not be influenced by gender. More specifically, Carter and Rosa (1998) and Marlow and Patton (2005) argued that concepts of gender and entrepreneurship limit women's ability to accrue social, cultural, human, and financial capital and, furthermore, they place limitations on their ability to generate personal savings and to have credit histories that are attractive to resource providers, thereby impacting on the growth of such businesses.

Many SMMEs fail at the infancy stage and some fail a few years after startup. It is estimated that 50 percent of all start-ups fail in their first year, while 75 percent fail within the first three to five years in the United States of America (Anderson \& Dunkelberg, 1990, cited in Ladzani \& Van Vuuren, 2002). Data on SMMEs in South Africa suggest that they contribute about half of total employment and therefore play an important role in the economy. For instance, the SMME sector makes up more than $95 \%$ of the total enterprises, contributing more than half of the employment, and approximately 35\% to the total Gross Domestic Product (GDP).

Mintzberg (1989) stated that barriers to SMME survival and growth are likely to be faced in all four functional areas of business operation - management, marketing, operations, and finance - and may be directly related to the size and start-up conditions of the SMMEs. In recent years, the South African government has provided training for SMMEs, focusing on basic literacy, numeracy, and communication skills to a limited few would-be entrepreneurs.

Radipere and Van Scheers (2005) recommend that education and training should, additionally, focus on administration, financial management, and marketing skills.

Marketing, as part of business training, constitutes an important part of promoting SMMEs. Jackson (2004) argues that access to micro-credit is not the primary constraint to small enterprise development and growth; but instead, there is an increasing shift toward recognition of the critical importance of non-financial constraints, such as the lack of information and the lack of management and business skills. It is through the delivery of education and business training that these non-financial constraints can best be addressed.

Women participating in meaningful entrepreneurial activity have, until recently, been stifled for various reasons, including having a low education level; and as a result, their level of involvement in sustainable and valueadding entrepreneurial activity has been relatively low. It would be of interest to policymakers and academics to establish to what extent gender plays a role in the growth of a business. Most studies on the growth of firms have focused on large companies or new ventures; while the growth of established SMMEs seems to have attracted much less attention.Thus, the aim of this study is to examine the relationship between the level of education of the SMME owner/manager and the growth of a business from a gender perspective in the Western Cape Province of South Africa - a developing nation.

\section{LITERATURE REVIEW}

According to the World Bank (2006), within the context of development, countries can be broadly classified into those that are already developed and those that are still developing. The term 'developed country' is used to describe those that have a high level of development according to some specific criteria. Economic criteria have tended to dominate such discussions. One such criterion is income per-capita, and countries with high levels of gross domestic product (GDP) per capita are described as developed countries. Another useful economic criterion is industrialization. The World Bank (2008) asserts that South Africa is characterized as a developing country.

However, South Africa has a two-tiered economy - one rivaling other developed countries and the other with only the most basic infrastructure. South Africa is regarded as a productive and industrialized economy that exhibits many characteristics associated with developing countries, such as an uneven distribution of wealth, a high level of poverty, and a high level of unemployment.

Kirstein (2006) refers to the two-tiered economy as comprising the first and second economies. The notion of two economies in South Africa is a metaphor implying that part of the South African economy is cutting-edge and global and a part is marginalized and underdeveloped. Kirstein (2006) further argues that despite government's 
claims that there has been some progress in development since the democratic elections in 1994, these claims cannot be substantiated by any real factual evidence. The number of people that are in the second economy continues to grow. Unemployment in South Africa stands at 25\% (Statistics SA, 2012), which is still one of the highest in the world.

Poverty is rampant and income distribution is grossly uneven; these are some of the development challenges facing South Africa in the twenty-first century. The World Bank (2008) identifies the three major development challenges facing South Africa - high levels of poverty, income inequality, and unemployment. The South African government contends that solving these three development challenges is a primary objective and it is through education that these challenges could be overcome.

According to earlier studies by Guzman (1994), the entrepreneurial quality of the SMME owner is a critical factor affecting SMMEs' ability to overcome barriers to survival and to achieve sustainable growth. A combination of formal and on-the-job training may be seen as one of the key factors that lays the foundation for success. Education is thought to increase the intrinsic motivation and to energize behaviours (Guzman \& Santos, 2001). The more enterprising education an individual receives, the greater the possibility of entrepreneurial success (Scott \& Gibb, 1986) and the growth of such a business. Cooper, Gimeno-Gascon and Woo (1994) found that education of the entrepreneurs has a significant effect on their survival and on the growth of such an enterprise.

Similarly, the study of Kangasharu and Pekkala (2002) in Finnish found that higher levels of education of an owner contribute to higher business growth in enterprises run by such people. It is widely known that entrepreneurship is now becoming an increasingly important source of employment for women in many countries. Arenius and Minniti (2005) add that women play an important role in the growth process of a country. No clear evidence has been found on the relationship between education and entrepreneurship, however (Blanchflower, 2004), although basic literacy seems to be a requirement for starting a new business - for both men and women (Reynolds, Bygrave, Autio, Cox and Hay, 2003).

A study by Ghosh (2002) in India argues that a more direct single-domain condition, such as a lack of technical skills developed in schools or vocational training, contributes to the subordination of women in poorer socio-economic areas. He adds that girls are prevented from participating in skills-based education by family choice or by social norms. In South Africa, not having specific skills can prevent many women from venturing into starting self-employed businesses.

The literature on business growth is extensive (Moreno \& Casillas, 2007), but researchers argue that it deserves greater focus from researchers, given its importance in job creation and in social and economic development (Barringer, Jones \& Neubaum, 2005; Moreno \& Casillas, 2007). While it is not the purpose of this study to review this broad area of business growth in any great depth, it is nevertheless useful to summarize some of the key factors which consistently emerge before narrowing the focus to SMME growth.

A definition of growth may be conceptualised by the various levels of sales over a defined period and/or employee growth (Garnsey, Stam \& Heffernan, 2006; Moreno \& Casillas, 2007). While sales volume is a common growth measure, it can be argued that sales are dependent on external factors, such as inflation and exchange rates. Employment growth, on the other hand, is not dependent on such external factors to as great a degree (Delmar, Davidsson \& Gartner, 2003); therefore, this is a better measure of business growth. Research has also shown that SMMEs' growth and competitiveness is constrained by the lack of access to adequate financing (Ogujiuba, Ohuche \& Adenuga, 2004; Berger \& Udell, 2006).

SMMEs, it seems, live in a world where growth is the normative expectation. However, they are frequently unable to grow due to informational asymmetry, which results in a finance gap that contributes to the inability to grow (Vos, Yeh, Carter \& Tagg, 2007). Notwithstanding this, many SMMEs are growing beyond the size that informal sources of finance can support; therefore, institutional credit is the only feasible option for financing growth (Wattanapruttipaisan, 2003). Large and/or growing enterprises do not necessarily equate to profitable ventures (Davidsson, Steffens \& Fitzsimmons, 2005). Business growth can have desirable and undesirable consequences. 
The undesirable consequences include loss of the "informal and family-like character of the small organisations" (Davidsson, Achtenhagen \& Naldi, 2007), a concern with losing control of the business, and a reduction in one's work-life balance (Cliff, 1998). SMMEs rely on internal sources of funds in their early years of operation and as they grow in size and age, they require better access to external funds in order to support their growth.

In the absence of transparent disclosure, SMMEs are less able to send credible signals to venture capitalists, banks, or trade creditors, implying that SMMEs have limited access to external funds due to informational asymmetries, thereby impeding SMMEs accumulation of revenue-generating assets and their potential growth. The literature reveals that most SMMEs do not opt for rapid growth and that most SMME owners prefer to retain control by not applying for external capital (Curran, Bolton \& Britain, 1986; Jarvis, 2000, cited in Vos et al., 2007).

In relation to business growth, the type of business sector also may be affected by growth. Service businesses, in general, have received little attention. Service businesses may have different growth patterns than those of manufacturing businesses (De Jong \& Vermeulen, 2006), and even within the service sector, different types of businesses tend to have lower growth aspirations than do entrepreneurs who have satisfactorily established their own manufacturing businesses (Kolvereid,1992; Wilson \& Morris, 2000). This lower growth expectation for the service sector thus raises a potential concern for a developing country, like South Africa, that is so dependent on the service sector, which is the largest sector in the country.

Gender also appears to impact growth. Stoner, Hartman and Arora (1990) argued that women-owned businesses are especially affected by conflicts between home and family demands, and these conflicts may have deliberate or inadvertent implications for growth. It has been suggested that a primary hurdle faced by women aspiring to develop high-growth businesses is the inability to obtain financing (Morris, Miyasaki, Watters \& Coombes, 2006). The businesses traditionally started by female entrepreneurs (retail and service) may very well influence the lack of (or slower growth) and the smallness of the businesses (Catley \& Hamilton, 1998; Kalleberg \& Leicht, 1991).

In the early stages of a business, the possibility of funding can be crucial both for business survival and growth. Brush, Carter, Gatewood, Greene and Hart (2004a) assert that a funding gap hinders the growth of womenowned businesses. Moreover, undercapitalization has also been identified as a major source of lower growth (Carter, 2000; Marlow \& Patton, 2005).

Earlier research revealed that women start their own businesses to a lesser degree than do men and those few who do take this step seem to achieve less growth in their businesses than do their male counterparts (Cliff, 1998). Undercapitalization has been identified as a major source of lower growth and the poor performance of women-owned businesses (Carter, 2000; Marlow \& Patton, 2005). Most studies on business growth have focused on businesses that have passed the early growth stage. Thus, knowledge on the business funding in the start-up phase and early business growth is scarce, especially when gender is the focus (Alsos, Isaksen \& Ljunggren, 2006).

Women-owned businesses are often presented as performing less on indicators, such as revenues, income level, business size, and rates of growth. Lack of growth could be due to a funding gap (Brush, Carter, Gatewood, Greene \& Hart, 2004b).

According to Brush (1997) and Carter \& Allen (1997), the liberal feminism theory suggests that men and women begin with equal potential and that differences manifest because of systematic inequalities in education, employment opportunities, and experience. Women entrepreneurs, in developed countries with higher education, show a larger interest in growing their own enterprises (Welter, 2006). Isaksen and Kolvereid (2005) found that women business founders have lower growth ambitions than do those started by men. Women had lower total assets and lower levels of equity than men. Women-owned businesses obtained lower sales levels than those of men.

Fewer differences were detected when it comes to their perceptions and behaviours related to obtaining financial resources for developing and growing their businesses. Woman entrepreneurship is now considered one of the sources of growth, employment, and innovation. Hence, policymakers and governments should attempt to reduce the barriers to start-ups and business growth for women entrepreneurs. 
Findings by Cliff (1998) revealed that women also seem to be more concerned with the risks associated with fast-paced growth and they tend to deliberately adopt a steady rate of expansion as personal considerations appear to override economic considerations in the business-expansion decision. The desire expressed by women for not letting growth get "out of control" also has important implications for financial-capital providers. This managed approach to business expansion may result in ventures that are able to out-survive those headed by entrepreneurs pursuing more risky, high-growth strategies.

In general, the performance and growth of female-owned businesses, in terms of turnover, profit realization, and employment growth, are weaker than those found in male-owned businesses (Rosa et al., 1996; Carter et al., 2001). Brush et al. (2004) initial findings confirmed that “. . . women often lacked the economic power and the social and family-support structure to grow their ventures" and the lack of adequate childcare might have forced them to keep their businesses smaller and more manageable (Brush et al., 2004). They also found that one of the most important reasons for the slower growth of women-owned businesses was that women encounter social structures in work, family, and social life that influence the development of human and social capital different from their male counterparts.

While feminism provides one perspective on gender differences on entrepreneurship, some scholars have criticized this approach. Belenky, McVicker, Clinchy, Goldberger, and Tarule (1986) stated, "If and when scientists turn to the study of women, they typically look for ways in which women conform to or diverge from patterns found in the study of men." Moreover, Brush (1992) described such a rationale as "entrepreneurs-as-male", whereas women-business owners are typically described as having "less", "smaller", or "fewer" desirable qualities (such as management experience, education, access to resources, and risk propensity).

Thus, examining the influence of gender by comparing female with male business owners, it fails to recognise that gender influences reside not only in the owner, but also in other areas like social structure, education, and politics.

Earlier studies, such as those of Cooper, Gimeno-Gascon, and Woo (1994) and Fischer, Reuber, and Dyke (1993), showed that women-owned businesses grow less quickly than those owned by men. A number of authors have begun to challenge the idea that the growth of an organisation is a naturally occurring phenomenon, proposing instead that expansion is at least partially determined by the entrepreneur's motivations and intentions for the business (such as the studies by Bird \& Jelinek, 1988; Cooper, 1993; Kolvereid, 1992). The results of several studies indicate that many women-owned businesses deliberately choose to keep their businesses small, thereby limiting business growth (e.g. Lee-Gosselin \& Grise, 1990; Kaplan, 1988; Goffee \& Scase, 1985, cited in Cliff, 1998) or they have conservative growth expectations (Belcourt, Burke \& Lee-Gossiping, 1991; Chaganti, 1986).

According to Kesper (2001), most new SMMEs in South Africa lack profitability and growth. Many SMMEs do not report a profit or an increase in turnover. Their constraints include: 1) poor micro-economic conditions and more price-competitive imports coming into the domestic market, 2) an increase in wages can erode the price competitiveness of SMMEs, 3) sales of SMMEs are primarily concentrated on the local markets, and 4) they have high input costs, especially transport and labour costs.

Over the years, there has been some research on the business-owners gender and access to debt capital (Carter, Shaw, Wilson \& Lam, 2006, cited in Alsos et al., 2006; Fabowale, Orser \& Riding, 1994) but little related to gender and business growth. The knowledge on business funding in the start-up phase and early business growth is scarce, especially when gender is the focus (Alsos et al., 2006). According to the literature, education is seen to be associated with business growth. It is, therefore, the intention of this study to establish whether there is any relationship between education and business growth in a developing nation and to establish whether gender is related to business growth in any way. Against the background of the discussion above, the following relationships are hypothesised:

$\mathbf{H}_{1}$ : The growth of a business is independent of gender.

$\mathbf{H}_{2}$ : There is a relationship between the level of education and business growth. 


\section{METHODOLOGY}

The study adopted a quantitative approach, using a survey method in the form of a questionnaire. The sample comprised SMME owners based in and around the City of Cape Town. Cape Town contributes $71 \%$ to the total gross geographic product (GGP). Contact was with 912 randomly selected SMME owners/managers in and around the City of Cape Town, of the Western Cape Province of South Africa. Of the total contacts, 379 of the SMME owners/managers were found to be usable in this study, indicating a response rate of $40 \%$. Further interviews were also conducted in towns on the South Coast and West Coast of the province. The criteria applied for participation in the survey were: 1) The business had to have been in existence for more than one year and it should not be classified as survivalist; 2) All businesses had to be involved in the following sectors - manufacturing (or some derivative thereof), retailing, agribusiness, and transport, which - if one excludes the financial services and building sectors - contribute a significant portion to the provinces GGP.

Further, these criteria ensured the inclusion of owners/managers with a reasonable understanding of minimum wage, turnover, government initiatives and the concept of Black Economic Empowerment (BEE). However, there were instances where secondary data had to be used, such as the Global Entrepreneurship Monitor report, previous research, government statistics and policies.

The reliability and validity of the research instrument was ascertained by undertaking a pilot study based on the comments from two academics in the field of entrepreneurship. The data were analyzed using an SPSS package, version 20. Descriptive statistics and chi-square analyses were used to present the results. Chi-square analysis was used to test the hypotheses for associations between the variables. The next section presents the findings and a discussion.

\section{FINDINGS AND DISCUSSION}

Business growth has been conceptualized and measured in a number of different ways. A review of fiftyfive empirical articles on growth by Delmar (1997) found that $31 \%$ of the studies used turnover/sales, while $29 \%$ used employee growth, as measures of business growth. Similarly, a recent study by Achtenhagen, Naldi and Melin (2010), using 56 articles, found that $42 \%$ used sales/turnover, $27 \%$ used employee growth, and $18 \%$ used the intention to grow. In the current study, business growth was measured by changes in sales growth and employee growth, as defined by Garnsey, Stam and Hefferman (2006) and Moreno and Casillas (2007).

\section{Demographics}

The demographic variables for which the data were collected, and the information obtained, included gender, age of business owner, age of business, education level of SMME owner, sector of business, and legal form of ownership. The demographics are presented below. Visual distributions of the demographic variables are presented in the form of tables. The total sample was 379 SMME owners, which consisted of $71 \%$ (271) men and $29 \%$ (108) women entrepreneurs. As this was a random sample, this clearly indicates that that are fewer female business owners than male business owners. The ages of the owners were categorized, differentiating between the men and women entrepreneurs, as shown in Table 1. As many as $48 \%$ of the SMME owners were in the middle-age group (40-49 years).

The results reveal that entrepreneurs are starting businesses at a later stage in their life. However, in the age group 30-39, there were approximately twice the numbers of females compared to males, which was significant $(\mathrm{p}<0.05)$. This implies that females are starting businesses at a younger age than are their male counterparts. 
Table 1: Age Of Owner

\begin{tabular}{|l|c|c|c|}
\hline & \multicolumn{2}{|c|}{ Gender* } & Temale \\
\hline Age & Male & $5.6 \%$ & $4.8 \%$ \\
\hline From 17 to 29 & $4.5 \%$ & $31.8 \%$ & $20.3 \%$ \\
\hline From 30 to 39 & $15.7 \%$ & $33.6 \%$ & $48.0 \%$ \\
\hline From 40 to 49 & $53.7 \%$ & $25.2 \%$ & $24.3 \%$ \\
\hline From 50 to 59 & $23.9 \%$ & $3.7 \%$ & $2.7 \%$ \\
\hline 60 and over & $2.2 \%$ & $100.0 \%$ & $100.0 \%$ \\
\hline Total & $100.0 \%$ & & \\
\hline
\end{tabular}

$* \mathrm{p}<0.05$

Respondents were requested to indicate the level of education based on five categories. Table 2 shows that most of the respondents had a diploma (36\%), followed by grade $12(31 \%)$, a degree (28\%), below Grade $12(3 \%)$, and postgraduate $(2 \%)$. Gender was cross-tabbed with education in order to establish whether there was any significant difference between male and female owners. In order to facilitate the analyses, the education levels were collapsed into two categories - educated (post-Grade 12 qualification) and not educated (Grade 12 and below). A total of $64 \%$ of the respondents were regarded as educated.

Table 2: Gender And Education

\begin{tabular}{|l|c|c|}
\hline & \multicolumn{2}{|c|}{ Education } \\
\hline \multicolumn{1}{|c|}{ Gender } & Not Educated & Educated \\
\hline Male & $35.4 \%$ & $64.6 \%$ \\
\hline Female & $38.9 \%$ & $61.1 \%$ \\
\hline Total & $36.4 \%$ & $63.6 \%$ \\
\hline
\end{tabular}

As may be noted in Table 2, a slightly higher percentage $(65 \%)$ of men than women $(61 \%)$ were educated. However, this was not significant, thereby implying that male and female entrepreneurs were equally educated.

\section{Gender And Growth}

Business growth was measured by changes in sales growth and employee growth, as defined by Garnsey, Stam and Hefferman (2006) and Moreno and Casillas (2007). Respondents were requested to indicate whether their number of employees had changed in the past two years. As much as $67 \%$ of the total respondents indicated that their labour force had expanded. A total of $68 \%$ of male-owned businesses, compared to $63 \%$ of female-owned businesses had expanded. Although not significant, male entrepreneurs had a greater increase in labour compared to female entrepreneurs, as is shown in Table 3.

Table 3: Gender And Labour Growth

\begin{tabular}{|l|c|c|c|}
\hline \multicolumn{1}{|c|}{ Gender } & \multicolumn{2}{c|}{ In the past two years has your labour force? } \\
\hline & Expanded & Contracted & Not Changed \\
\hline Men & $68.2 \%$ & $7.9 \%$ & $24.0 \%$ \\
\hline Women & $63.2 \%$ & $6.6 \%$ & $30.2 \%$ \\
\hline
\end{tabular}

Respondents were also required to indicate whether they had experienced an increase in turnover/sales over the past two years, using inflation as a benchmark. A total of $83 \%$ of the respondents indicated an increase in turnover. As noted in Table 4, $84 \%$ of men compared to $81 \%$ of women had experienced an increase in turnover. Thus, there was no significant difference from the perspective of gender. Thus, male and female entrepreneurs had experienced an equal growth in sales.

Table 4: Gender And Turnover

\begin{tabular}{|l|c|c|}
\hline \multicolumn{1}{|c|}{ Gender } & Did your turnover increase by more than the inflation rate in the past two years? \\
\hline & Yes & No \\
\hline Men & $83.6 \%$ & $16.4 \%$ \\
\hline Women & $81.1 \%$ & $18.9 \%$ \\
\hline
\end{tabular}


It is known from literature that the performance and growth of woman-owned businesses, in terms of turnover, profit realization and employment growth, is weaker than that found in man-owned businesses (Rosa et al., 1996; Carter et al., 2001). The initial findings of Brush et al. (2006) confirmed that “. . . women often lacked the economic power and the social and family support structure to grow their ventures" and, additionally, the lack of adequate childcare might have forced them to keep their businesses smaller and more manageable (Brush et al., 2004). They also found that one of the most important reasons for the slower growth of women-owned businesses was that women encounter social constraints in work, family, and social life that influence the development of human and social capital differently from their male counterparts.

The current study, however, did not reveal any significant differences in growth patterns between men and women entrepreneurs, thus refuting previous studies that growth patterns are different for men and women.

\section{Education and Business Growth}

Education was cross-tabbed with labour growth and turnover to establish whether there was an association between these variables. From Table 5, it may be noted that a higher proportion (73\%) of those respondents who indicated that the business had expanded, were educated. The results indicated an association ( $\mathrm{p}$ $<0.05$ ) between education and increase in labour force, meaning that a business is more likely to grow its labour force if the business owner is educated. Similarly, as shown in Table 6, 67.5\% of the respondents who were educated, compared to $32.5 \%$ who were not educated showed an increase in turnover. This was also significant $(\mathrm{p}<0.050)$, implying that SMME owners who were educated, were more likely to report increase in turnover than those owners who were not educated.

This further confirms that education is associated with business growth.

Table 5: Education And Labour Growth

\begin{tabular}{|l|c|c|c|}
\hline & \multicolumn{2}{|c|}{ In the past two years has your labour force? } \\
\hline \multicolumn{1}{|c|}{ Education } & Expanded & Contracted & Not Changed \\
\hline Not educated & $26.9 \%$ & $53.6 \%$ & $56.2 \%$ \\
\hline educated & $73.1 \%$ & $46.4 \%$ & $43.8 \%$ \\
\hline
\end{tabular}

Table 6: Education And Turnover

\begin{tabular}{|l|c|c|c|}
\hline \multicolumn{1}{|c|}{ Education } & \multicolumn{2}{c|}{ Did your turnover increase by more than the inflation rate in the past two years? } \\
\hline & Yes & No & Total \\
\hline Not educated & $32.5 \%$ & $53.1 \%$ & $36 \%$ \\
\hline Educated & $67.5 \%$ & $46.9 \%$ & $64 \%$ \\
\hline
\end{tabular}

Cooper, Gimeno-Gascon, and Woo (1994) found that the educational level of the entrepreneurs has a significant effect on the survival and growth of an enterprise. Similarly, the study of Kangasharu and Pekkala (2002), in Finnish, found that higher education contributed to higher business growth. Thus, the current study supports previous studies that education and business growth are indeed positively associated.

In contrast, other studies (those of Chandler and Hanks, 1994; Sirmon and Hitt, 2003) showed that most women-owned businesses show slowing down, or no growth due to the lack of business and management skills. This supports a need for design and delivery of specific business and technical training programmes by business support organisations for fostering the growth of businesses, thereby creating more employment. As found in this current study, education is associated with business growth.

Thus, Hypothesis 1, which states that business growth is independent of gender is supported, indicating that gender and business growth are independent of one another. There were no significant differences between men and women in relation to business growth. Hypothesis 2, which states that education and business growth are related, was also supported. 


\section{CONCLUSION}

This article intended to establish whether education is associated with business growth and whether gender is associated with growth. Analysing business growth in this study, only two criteria were adopted - turnover and employee growth. The study found that $66 \%$ of business owners had a post-grade 12 qualification. There were no significant differences between gender and education, and between gender and growth. However, it was found that education was associated with business growth, using labour-force growth and turnover as growth variables. There are here important implications for policymakers, especially the government, in creating support mechanisms, which provide advice, training, as well as business education and access to finance and networks. Future research should look at industry-specific issues and establish whether or not gender is a contributing factor in business growth - and if there are differences found, the reasons for them.

\section{AUTHOR INFORMATION}

Pradeep Brijlal is a senior lecturer in the School of Business and Finance at the University of the Wetsern Cape, South Africa. He lectures in Financial Management, Business Finance, and various management modules. He is also a reviewer of journal articles, examiner and supervisor of master's students. His research interests are in the fields of entrepreneurship, entrepreneurship education, business finance and investments. E-mail: pbrijlal@uwc.ac.za (Corresponding author)

Visvanathan Naicker $(\mathrm{PhD})$ teaches Management Information Systems, Business Information Systems, Retail Management \& General Management. Research focus areas are SME's development, Computers \& Education, Consumer \& Retail Behavior, and Information Systems. HOD of Master's \& Doctoral research in the SBF, Lectures in Undergrad, Post-grad and Masters programs in the SBF. E-mail: vnaicker@uwc.ac.za

Ricardo Peters $(\mathrm{PhD})$ is an accomplished academic leader and currently heads the fastest growing business school in South Africa. He has experience from both the corporate world and in academia. His area of research is Economic Development from an SMME perspective. Ricardo Peters also teaches Investments, Financial Planning, Management and Entrepreneurship. His passion for community transformation has resulted in him initiating sustainable development programmes in disadvantaged communities in Cape Town. E-mail: rmpeters@uwc.ac.za

\section{REFERENCES}

1. Achtenhagen, L., Naldi, L., Melin, L. (2010). Business growth- do practitioners and scholars really talk about the same thing? Entrepreneurship Theory and Practice, 34(2) 289-316.

2. Acs, Z.J., Arenius, P., Hay, M. \& Minniti, M. (2005). Global entrepreneurship monitor: 2004 executive report. Available at http://www.gemconsortium.org, accessed September 7, 2006.

3. Alsos, G. A., Isaksen, E. J. \& Ljunggren, E. (2006). New Venture Financing and Subsequent Business Growth in Men-and Women-Led Businesses. Entrepreneurship theory and practice, 30(5) 667-686.

4. Anderson, R. L. \& Dunkelberg, J. S. (1990). Entrepreneurship: Starting a new business. Harper and Row New York.

5. Ang, J. S. (1992). On the theory of finance for privately held firms. Journal of Small Business Finance, l(3) 185-203.

6. Arenius, P. \& Minniti, M. (2005). Perceptual variables and nascent entrepreneurship. Small business economics, 24(3) 233-247.

7. Barringer, B. R., Jones, F. F. and Neubaum, D. O. (2005). A quantitative content analysis of the characteristics of rapid-growth firms and their founders. Journal of Business Venturing, 20(5) 663-687.

8. Belcourt, M., Burke, R. and Lee-Gossiping, H. (1991). From the frying pan into the fire: Exploring entrepreneurship as a solution to the glass ceiling. Journal of small business and entrepreneurship, 8(3) 49 55.

9. Berger, A. N. and Udell, G. F. (2006). A more complete conceptual framework for SME finance. Journal of Banking \& Finance, 30(11) 2945-2966.

10. Belenky, M., McVicker Clinchy, B., Goldberger, N. and Tarule, J. (1986). Women's ways of knowing. New York: Basic Books, Inc. 
11. Bird, B. and Jelinek, M. (1988). The operation of entrepreneurial intentions. Entrepreneurship Theory and Practice, 13(2), 21-29.

12. Blanchflower, D. G. and Oswald, A. J. (2004). Wellbeing over time in Britain and the USA. Journal of Public Economics, 88(7) 1359-1386.

13. Brush, C., Carter, N., Gatewood, E., Greene, P. \& Hart, M. (2004). Clearing the hurdles: Women building high-growth businesses. FT Press.

14. Brush, C. G., Carter, N. M., Gatewood, E., Greene, P. \& Hart, M. (2004). Gatekeepers of venture growth: a Diana Project report on the role and participation of women in the venture capital industry. Available at SSRN 1260385.

15. Brush, C. (1992). Research on women-business owners: Past trends, a new perspective and future directions. Entrepreneurship Theory and Practice, 16(4) 5-30.

16. Brush, C.G. (1997). Women-owned businesses: Obstacles and opportunities. Journal of Developmental Entrepreneurship, (2) 1-24.

17. Carter, S. (2000). Gender and enterprise. Enterprise and Small Business. Principles, Practice and Policy, Harlow: Prentice Hall/Pearson Education Limited, 166-181.

18. Carter, S. \& Jones-Evans, D. (2001). Enterprise and small business: principles, practice and policy. $\mathrm{Ft}$ Press.

19. Carter, S., Shaw, E., Wilson, F. \& Lam, W. (2006). Gender, entrepreneurship and business finance: Investigating the relationship between banks and entrepreneurs in the UK. In C.G. Brush, N. M. Carte, E. J. Gatewood, P. G. Greene, \& M. M. Hart (Eds.), Growth-oriented women entrepreneurs and their businesses-A global research perspective (pp. 373-392). Cheltenham, UK: Edward Elgar.

20. Carter, S. 2000. Improving the numbers and performance of women-owned businesses: some implications for training and advisory services. Education and Training, 42(4/5) 326-334.

21. Carter, S. and Rosa, P. (1998). The financing of male- and female owned businesses. Entrepreneurship and Regional Development, 10(3) 225-242.

22. Carter, N.M. and Allen, K.R. (1997). Size determinants of women-owned businesses: Choice or barriers to resources? Entrepreneurship and Regional Development, 9, 211-220.

23. Catley, S. \& Hamilton, R. T. (1998). Small business development and gender of owner. Journal of Management Development, 17(1) 75-82.

24. Chaganti, R. (1986). Management in women-owned enterprises. Journal of Small Business Management, 24(4), 18-29.

25. Census South Africa. (2011). http://www.southafrica.info/about/people/population.htm\#.URNo9PI-JvI. (accessed 2 February 2013).

26. Chandler, G. \& Hanks, S. (1994). Market attractiveness, resource- based capabilities, venture strategies and venture performance. Journal of Business Venturing, 9(4) 331-349.

27. Cliff, J. E. (1998). Does one size fit all? Exploring the relationship between attitudes towards growth, gender, and business size. Journal of Business Venturing, 13(6) 523-542.

28. Coleman, S. 2007. The role of human and financial capital in the profitability and growth of women-owned small firms. Journal of Small Business Management, 45(3) 303-319.

29. Cooper, A. C. (1993). Challenges in predicting new firm performance. Journal of Business Venturing, 8(3), 241-253.

30. Cooper, A. C., Gimeno-Gascon, F. J. \& Woo, C. Y. (1994). Initial human and financial capital as predictors of new venture performance. Journal of Business Venturing, 9(5) 371-395.

31. Curran, J., Bolton, J. E. \& Britain, G. (1986). Bolton Fifteen Years on: A Review and Analysis in Britain 1971-1986. Small Business Research Trust.

32. Davidsson, P., Steffens, P. \& Fitzsimmons, J. (2005). Growing profitable or growing from profits: Putting the horse in front of the cart. Paper presented at the Academy of Management Meeting, Honolulu.

33. Davidsson, P., Achtenhagen, L. \& Naldi, L. (2007). Research on small firm growth: A review. Available at http://eprintsqut.edu.au/2072/1/EISB version_Research_on_small_firm_growth.pdf, accessed 22 August, 2009.

34. De Bruin, A., Brush, C.G. \& Welter, F. (2006). Introduction to the special issue: Towards building cumulative knowledge on women's entrepreneurship. Entrepreneurship Theory \& Practice, (30) 585-592.

35. De Jong, J. P. J. \& Vermeulen, P. A. M. (2006). Determinants of Product Innovation in Small Firms A Comparison Across Industries. International Small Business Journal, 24(6) 587-609. 
36. Delmar, F., Davidsson, P. \& Gartner, W. B. (2003). Arriving at the high-growth firm. Journal of Business Venturing, 18(2) 189-216.

37. Delmar, F. (1997). Measuring growth: methodological considerations and empirical results, in Entrepreneurship and SME research: on its way to the next millennium, R. Donckels \& A. Miettinen (eds.), 199-215. Aldershot: Ashgate.

38. Dobs, M . \& Hamilton, R.T. (2007). Small business growth: recent evidence and new directions, International journal of Entrepreneurial behaviour and Research, 13(5)296-322.

39. DTI. (2008). Towards the review of SMME definitions in South Africa. Annual National SMME Summit: South Africa.

40. Fabowale, L., Orser, B. \& Riding, A. (1994). Gender, structural factors, and credit terms between Canadian small businesses and financial institutions. Faculty of Business, Ryerson Polytechnic University.

41. Fischer, E. M., Reuber, A. R. \& Dyke, L. S. (1993). A theoretical overview and extension of research on sex, gender, and entrepreneurship. Journal of Business Venturing, 8(2) 151-168.

42. Garnsey, E., Stam, E. \& Heffernan, P. (2006). New firm growth: Exploring processes and paths. Industry and Innovation, 13(1) 1-20.

43. Gatewood, E.J., Carter, N.M., Brush, C.G., Greene, P.G. \& Hart, M.M. (2003). Women entrepreneurs, their ventures, and the venture capital industry: An annotated bibliography. Stockholm: ESBRI.

44. Goffee, R. \& Scase, R. (1985). Women in charge: The experiences of female entrepreneurs. Allen \& Unwin London.

45. Ghosh, J. (2002). Globalization, export-oriented employment for women and social policy: A case study of India. Social Scientist, 30(11/12) 17-60.

46. Guzman, J. (1994). Towards a taxonomy of entrepreneurial theories. International Small Business Journal, 12(4) 77-88.

47. Guzmán, J. \& Santos, F. J. (2001). The booster function and the entrepreneurial quality: an application to the province of Seville. Entrepreneurship \& Regional Development, 13(3) 211-228.

48. Gürol, Y. \& Atsan, N. (2006). Entrepreneurial characteristics amongst university students: some insights for entrepreneurship education and training in Turkey. Education+ Training, 48(1) 25-38.

49. Isaksen, E. \& Kolvereid, L. (2005). Growth objectives in Norwegian start-up businesses. International Journal of Entrepreneurship and Small Business, 2(1) 17-26.

50. Jackson, P. L. M. (2004). Entrepreneurial support in South Africa: a case study of a small enterprise support centre in Johannesburg. University of Birmingham.

51. Kangasharju, A. \& Pekkala, S.( 2002). The Role of Education and Self-Employment Success in Finland. Growth and Change, (33) 216-237.

52. Kalleberg, A. L. \& Leicht, K. T. (1991). Gender and organizational performance: Determinants of small business survival and success. Academy of Management Journal, 34(1) 136-161.

53. Kaplan, E. 1988. Women entrepreneurs: Constructing a framework to examine venture success andfailure. In B. A. Kirchhoff, W. A. Long, W. Ed McMullan, K. H. Vesper, \& W. E. Wetzel, Jr.(Eds.), Frontiers of Entrepreneurial Research. Boston, MA: Babson College, 643-653.

54. Kesper, A. (2001). Failing or not aiming to grow? Manufacturing SMMEs and their contribution to employment growth in South Africa. Urban Forum, (12) 171-203.

55. Kirstein, A. (2006). Address by President Thabo Mbeki to the national council of provinces: the second economy, what it is. And what is needed to meet the growth and development challenges it presents? [online]. Available: http://www.sarpu.org.za/documents

56. Kirkwood, J. (2009). To grow or not ? growing small service firms. Journal of Small Business and Enterprise Development, 16(3) 485-503.

57. Kolvereid, L. (1992). Growth aspirations among Norwegian entrepreneurs. Journal of Business Venturing, 7(3) 209-222.

58. Ladzani, W. M. \& Van Vuuren, J. J. (2002). Entrepreneurship training for emerging SMEs in South Africa. Journal of Small Business Management, 40(2) 154-161.

59. Lee-Gosselin, H. \& Grisé, J. (1990). Are women owner-managers challenging our definitions of entrepreneurship? An in-depth survey. Journal of Business Ethics, 9(4), 423-433.

60. Lewis, P., Saunders, M. N. K. \& Thornhill, A. (2003). Research methods for business students (3rd ed.). Prentice Hall, Upper Saddle River. 
61. Marlow, S. \& Patton, D. (2005). All credit to men? Entrepreneurship, finance, and gender.

Entrepreneurship Theory and Practice, 29(6) 717-735.

62. Mintzberg, H. (1989). Mintzberg on Management: Inside Our Strange World of Organizations The Free Press. New York.

63. Moreno, A. M. \& Casillas, J. C. (2007). High-growth SMEs versus non-high-growth SMEs: a discriminant analysis. Entrepreneurship and Regional Development, 19(1) 69-88.

64. Morris, M. H., Miyasaki, N. N., Watters, C. E. \& Coombes, S. M. (2006). The dilemma of growth: understanding venture size choices of women entrepreneurs. Journal of Small Business Management, 44(2), 221-244.

65. Ogujiuba, K. K., Ohuche, F. K. \& Adenuga, A. O. (2004). Credit Availability to Small and Medium Scale Enterprises in Nigeria: Importance of New Capital Base for Banks--Background and Issues. ideas. repec. org/p/wpa/wuwpma/0411002. html

66. Radipere, S. \& Van Scheers, L. (2005). Investigating whether a lack of marketing and managerial skills is the main cause of business failure in South Africa. South African Journal of economic and management sciences, 8(4) 402.

67. Reynolds, P. D., Bygrave, W. D., Autio, E., Cox, L. W. \& Hay, M. (2003). Global Entrepreneurship Monitor (GEM): Executive Report.

68. Rosa, P., Carter, S. \& Hamilton, D. (1996). Gender as a determinant of small business performance: insights from a British study. Small Business Economics. 8(6) 463-478.

69. Scott, M. \& Gibb, A. A. (1986). Understanding small firm growth. In M. Scott, A. A. Gibb, J.Lewis, \& T. Faulkner (Eds.), Small firm growth and development, pp. 81- 104. Hampshire, Gower.

70. Sirmon, D.\& Hitt, M.A. (2003). Managing resources: linking unique resources, management and wealth creation in family firms. Entrepreneurship Theory and Practice, 27(4) 339-358.

71. Statistics South Africa. (2012). Quarterly labour force survey.[online]. Available: http://www.statssa.gov.za/publication/find publication asp

72. Verheul, I. (2005). If there is a (fe)male approach? Understanding gender differences in entrepreneurship. Erasmus University, Rotterdam, Netherlands: ERIM PhD Series Research in Management.

73. Vos, E., Yeh, A. J. Y., Carter, S. \& Tagg, S. (2007). The happy story of small business financing. Journal of Banking \& Finance, 31(9), 2648-2672.

74. Wattanapruttipaisan, T. (2003). Four proposals for improved financing of SME development in ASEAN. Asian Development Review, 20(2), 66-104.

75. Welter, F. (2006). Women entrepreneurship in Germany: State of the art, progress and open questions. In C.G. Brush, N. M. Carter, E. J. Gatewood, P. G. Greene, \& M. M. Hart (Eds.), Growth-oriented women entrepreneurs and their businesses-A global research perspective (pp. 128-153). Cheltenham, UK: Edward Elgar.

76. Wilson, J. O. S. \& Morris, J. E. (2000). The size and growth of UK manufacturing and service firms. The Service Industries Journal, 20(2), 25-38.

77. World Bank. (2006). South Africa: enhancing the effectiveness of government in promoting micro, small and medium enterprises. Report for the Department of Trade and Industry: Pretoria.

78. World Bank. (2008). South African country brief [online]. Available: http://siteresource.worldbank.org/GILDSOUTHAFRICA/insolvency\%20law 